\title{
Coupling Genetic Addiction Risk Score (GARS) and Pro Dopamine Regulation (KB220) to Combat Substance Use Disorder (SUD)
}

\author{
Kenneth Blum ${ }^{1-10 *}$, Margaret A Madigan ${ }^{4}$, Lyle Fried ${ }^{7}$, Eric R Braverman ${ }^{6}$, John Giordano ${ }^{5}$ and Rajendra D \\ Badgaiyan $^{9}$ \\ ${ }^{1}$ Department of Psychiatry \& McKnight Brain Institute, University of Florida College of Medicine, USA \\ ${ }^{2}$ Department of Psychiatry and Behavioral Sciences, Keck Medicine University of Southern California, USA \\ ${ }^{3}$ Division of Applied Clinical Research \& Education, Dominion Diagnostics, USA \\ ${ }^{4}$ Department of Neurogenetics, Igene, USA \\ ${ }^{5}$ National Institute for Holistic Addiction Studies, USA \\ ${ }^{6}$ Department of Clinical Neurology, Path Foundation NY, USA \\ ${ }^{7}$ Division of Neuroscience Based Addiction Therapy, The Shores Treatment \& Recovery Center, USA \\ ${ }^{8}$ Eötvös Loránd University, Institute of Psychology, Europe \\ ${ }^{9}$ Department of Psychiatry, Wright State University Boonshoft School of Medicine and Dayton VA Medical Center, US \\ ${ }^{10}$ Division of Reward Deficiency Syndrome, Nupathways, Inc., Innsbrook, MO, USA
}

Submission: February 11, 2017; Published: February 23, 2017

*Corresponding author: Kenneth Blum, Department of Psychiatry, University of Florida College of Medicine, Gainesville, FL, USA; Tel: 352-2944911; Fax: 352-392-9887; Email: drd2gene@gmail.com

\begin{abstract}
Abbreviations: RDS: Reward Deficiency Syndrome; SMART ${ }^{\mathrm{T}}$ : Systematic Medical Approach to Reward Transformation; GARS: Genetic Addiction Risk Score; DNA: Deoxyribonucleic Acid; DRD2: Dopamine Receptor D2 Gene; MOA: Monoamine Oxidase; SNPs: Single-Nucleotide Polymorphisms; SSRs: Simple Sequence Repeats
\end{abstract}

\section{Introduction}

We are proposing a generalized approach based on the Reward Deficiency Syndrome (RDS) conceptualization called the Systematic Medical Approach to Reward Transformation (SMART"). This system consists of: early pre-disposition diagnosis (even in children) using the Genetic Addiction Risk Score (GARS) [1]; a validated RDS questionnaire [2]; urine drug testing during actual treatment that uses comprehensive analysis of reported drugs to determine compliance with prescription medications and non-abstinence illicit drugs [3]; and adjunctive treatment with a glutaminergic-dopaminergic optimization nutraceutical (KB220) to prevent relapse by induction of dopamine homeostasis [4].

\section{Understanding reward deficiency syndrome (RDS)}

I. RDS conceptualization

The biological processes of reward that underlie addiction to substances and all addictive, compulsive and impulsive behaviors are the basis of the RDS conceptualization [5,6]. RDS then is a deficiency, a hypodopaminergic condition that results from some combination of genetic variations, environmental stressors, and adverse molecular effects or blunting due to prolonged substance use or behavioral habituation [7-9]. The RDS concept was developed based on animal and human research that explored the molecular biology of neurotransmission, and behavioral genetics $[8,10,11]$. Understanding this concept, explained in the following paragraphs, is central to treating the abnormal psychology of personality and spectrum disorders, as well as, substance and non-substance (behavioral) addictions. To feel ordinary pleasure, complex interactions of neurotransmitters regulate the dopaminergic activity of the brain in the reward center -the mesolimbic system, particularly the nucleus accumbens. Individuals, who suffer from a lack of ordinary pleasure in their lives, are predisposed to use any means; substance or behavior, to activate dopamine release, relieve stress and feel healthy pleasure $[12,13]$. 


\section{Global Journal of Addiction \& Rehabilitation Medicine}

Genes are deoxyribonucleic acid (DNA), which directs the functional properties of proteins like neurotransmitters. Genetic alleles are unusual versions of a gene that can change genetic function they are called polymorphisms or variants. Early in the 1990 's a statistically significant association of severe alcoholism with a variant, the A1 allele of the Dopamine Receptor D2 Gene (DRD2) was discovered [14]. This variant was later associated with numerous other addictive, compulsive and impulsive behaviors. At the same time, a binding availability study found that functionally, the presence of the A1 allele resulted in lower dopamine receptor availability in the parts of the brain known to effect reward [15]. Other earlier studies had explored the role of neurotransmitters in pleasure. In the limbic neural circuitry serotonin, enkephalin, GABA, and dopamine work together in a complex cascade of activation and inhibition that result in the release of dopamine. Dopamine was identified as one of the most powerful neurotransmitters that control feelings of well-being and reward. Negative emotions and craving are the results of disruption of the intercellular brain reward cascade that leads to reduced dopamine availability [16].

\section{Hypodopaminergic function}

The hypodopaminergic trait is itself polygenetic (involves many genes) and may result from variations in a number of reward genes. Reward genes govern the function of the dopaminergic, serotonergic, endorphinergic, opioidergic, GABAergic, adrenergic, cholinergic pathways, as well as, many second messengers, like enzymes and mRNA. Many associations with other genes and these behaviors have also been identified [17]. Many genes that are involved in the function of the reward neurotransmitters in the brain have variations that result in hypodopaminergic function [10]. For example, individuals may have high Monoamine Oxidase (MOA) gene activity, an increased rate of mitochondrial dopamine catabolism, due to the effect of an allele. Other examples are reduced numbers of serotonergic receptors, due to polymorphisms of the 5-HT (2A) receptorgene $(-1438 \mathrm{~A} / \mathrm{G})$. Serotonin transporter gene 5-HTTLPR polymorphisms also reduce synaptic serotonin levels, due to the biallelic (short and long alleles) and triallelic polymorphisms (including rs25531 A/G a single nucleotide variation) [18].

\section{The epigenetics of stress and prolonged exposure}

In addition to genetic polymorphisms, which reduce the availability of dopamine in the synapse, prolonged stress and long -term substance abuse also result in reduced cascade function and decreased dopamine release and may have a cumulative effect on vulnerability to addiction and other RDS Behaviors $[19,20]$. Harmful molecular effects or blunting occur due to prolonged substance use [21,22]. The repeated release of high amounts of dopamine into the synaptic cleft induces prolonged, heightened postsynaptic receptor activity, resulting in receptor down-regulation and, for this reason, further decreases dopamine function. Also, hypodopaminergic function, caused by genetic variations impacted by epigenetics, can induce impairments in the pre-frontal cortex-cingulated gyrus, which in turn leads to poor judgment and potential habit reinstatement or relapse $[20,22]$.

Receptor down-regulation reported, in both obese rats and drug-addicted humans, is the reason habituated addicts require ever increasing substance or behavior to maintain the rewarding effect $[20,23]$. However after prolonged abstinence dopamine receptor super-sensitivity, an enhanced biochemical response develops, and reinstatement at the previous level of habituation in the case of substance abuse may lead to fatalities [24]. Environmentally induced epigenetic effects on the chromatin structure of the DNA due to stress or triggered by cues can increase craving. Stress-triggered craving involves the neurotransmitters corticotrophin-releasing factor and norepinephrine. These neurotransmitters necessitate the abundant release of dopamine (100X times resting state) and subsequently, temporary hypodopaminergic functioning, repeated, or prolonged stress can induce a chronic hypodopaminergic state. Cue-triggered craving involves the basolateral nucleus of the amygdala, the hippocampus, and through glutaminergic activation, causes the increased release of dopamine that if chronic ultimately leads to a hypodopaminergic state. Due to this hypodopaminergic trait (genetic) and state (environmental), it is known that drug intake or aberrant behaviors will escalate $[25,26]$.

\section{Genetic addiction risk score (GARS)}

The Genetic Addiction Risk Score (GARS), is the first test to accurately predict vulnerability to pain, addiction, and other obsessive and compulsive behaviors, identified as RDS [27]. There is a need to classify patients at genetic risk to alcohol and drug-seeking behavior and relapse before or upon entry to pain and residential and or non-residential chemical dependency programs. Based on an extensive literature review, an addiction risk index consisting of 11 polymorphisms in 10 genes, involved in the neurological processing of reward, were identified and tested. The resulting genetic addiction risk score (GARS) included; six single-nucleotide polymorphisms (SNPs) in the DRD1, DRD2, DRD3, DRD4, COMT, and OPRM1 genes; four simple sequence repeats (SSRs) in the DAT1, DRD4, MAOA, and 5HTT transporter genes; and a dinucleotide polymorphism in the GABRA3 gene [9]. Blum's laboratory sought to address genetic risk for alcohol and drug by evaluating whether the combined effect of reward gene polymorphisms that contribute to a hypodopaminergic trait, associate with RDS related substance abuse risk. Among those who consented to provide a saliva sample for DNA genotyping, 273 (derived from seven centers) also had ASI phenotypic information.

The patient population $\mathrm{n}=393,17.6 \%, 80.7 \%$, and $1.5 \%$ scored in the low, moderate and high severity range, respectively. The mean number of GARS alleles was 7.97 (S.D. $=2.34$ ) and ranged between 3 and 17 alleles. The relationship between GARS genotype panel and the Alcohol Risk Severity Score using the Fishers Exact Test revealed a significant predicative relationship 


\section{Global Journal of Addiction \& Rehabilitation Medicine}

$(\mathrm{X} 2=8.84, \mathrm{df}=1, \mathrm{p}=0.004,2$-tailed $)$ that remained significant after controlling for age $(p<0.01)$. A similar, though less robust, relationship was obtained from chi-square $(p=0.05)$ and linear regression ( $b=-0.122, t=-1.91, p=0.10,2$-tailed) analyses of the ASI Drug Severity Risk Score. Blum et al. [28,29] details the construction of a genetic addiction risk score (GARS ${ }^{\mathrm{TM}}$ ) and its predictive relationship with ASI -MV derived alcohol and drug severity risk scores. Innovative strategies to combat epidemic opioid/opiate abuse, and death, based on the role of dopaminergic tone in pain pathways, are proposed. Sensitivity to pain may reside in the mesolimbic projection system, where genetic polymorphisms associate with a predisposition to pain vulnerability or tolerance. Pharmacogenomic testing of candidate genes like CB1, mu receptors, and PENK might result in pharmacogenomic, personalized solutions, and improved clinical outcomes. Identifying genetic risk for all RDS behaviors, especially in compromised populations, may be a frontline tool to assist municipalities in providing better resource allocation and possibly precision medicine [30].

\section{RDS questionnaire}

In conjunction with Zsolt Demetrovics in the Eötvös Loránd University, Institute of Psychology, Budapest, Hungary, an unpublished, 29 item RDS questionnaire reduced from 51 items generated based on the RDS theory, has been validated in over 1726 individuals attending college. The general reward deficiency factor was associated with gender, sensation seeking and impulsivity. Females show ahigher degree of reward deficiency trait. Greater sensation seeking and impulsivity predict higher degrees of reward deficiency and risk seeking behaviors and are positively associated with sensation seeking and impulsivity [2].

\section{Pro-Dopamine regulator (KB220)}

A glutaminergic-dopaminergic optimization nutraceutical called KB220 has been developed that supports the brain reward system and induces "dopamine homeostasis". This agonistic nutraceutical has been shown to safely provide substantial clinical benefit to the victims of RDS and assist in recovery from addiction to opiates/opioids and other substance and non-substance addictions and behaviors [7,17,31-33]. DNAdirected compensatory over expression of the DA D2 receptors (a form of gene therapy) has been shown to result in a significant reduction in alcohol and cocaine craving behavior in drugpreferring rodents [34,35] and acute in vitro bromocriptine a strong agonist-induced D2 receptor proliferation in rats [36]. KB220 variants formulations have been studied extensively in both animals and humans. Pre-clinical and human trials using a variety of methodologies are reported on in a detailed review article [37] and Table 1 lists the studies of KB220 variants in a multiplicity of RDS populations. Interestingly, in abstinent heroin addicts, a pilot study of a single dose of KB220Z compared to placebo found improvement of the prefrontal-cerebellaroccipital neural network and activation of the NAc [38].

Table 1: List of Clinical Studies: 1973 - 2016.

\begin{tabular}{|c|c|c|}
\hline \multicolumn{3}{|r|}{ Pre-clinical } \\
\hline Year & Reference & Key points \\
\hline 1973 & $\begin{array}{l}\text { Blum K, Calhoun W, Merritt J, et al. L-DOPA: } \\
\text { effect on ethanol narcosis and brain biogenic } \\
\text { amines in mice. Nature. } 242: 407-409 .\end{array}$ & $\begin{array}{l}\text { Increased brain L-DOPA increases brain dopamine in mice and causes inebriated mice } \\
\text { to sleep. Dopamine, 1-tryptophan and alcohol work similarly in the brain. }\end{array}$ \\
\hline 1974 & $\begin{array}{l}\text { Blum K, Wallace JE, Calhoun W, et al. Ethanol } \\
\text { narcosis in mice: serotonergic involvement. } \\
\text { Experientia 30:1053-1054. }\end{array}$ & $\begin{array}{l}\text { When mice were given alcohol and 1-tryptophan or saline the mice given 1-tryptophan } \\
\text { went to sleep. The mice given saline did not. 1-tryptophan and alcohol work similarly } \\
\text { in the brain. }\end{array}$ \\
\hline 1987 & $\begin{array}{l}\text { Blum K, Wallace JE, Trachtenberg MC, et } \\
\text { al. Enkephalinase inhibition: Regulation of } \\
\text { ethanol intake in mice. Alcohol: } 4 ; 449-456 .\end{array}$ & $\begin{array}{l}\text { Mice genetically predisposed to like alcohol have a measured deficiency in enkephalin. } \\
\text { D-phenylalanine and hydrocinnamic acid are substances known to stop the breakdown } \\
\text { of enkephalin in the brain -the amount of enkephalin available in the brain increases. } \\
\text { When the amount of enkephalin available in the brain increases both voluntary and } \\
\text { forced intake of alcohol decreases. D-phenylalanine is one of the ingredients in NAAT. }\end{array}$ \\
\hline \multicolumn{3}{|r|}{ Clinical } \\
\hline Year & Reference & Key points \\
\hline 1988 & $\begin{array}{l}\text { Blum K, Trachtenberg MC, Elliott CE, et al. } \\
\text { Improvement of inpatient treatment of the } \\
\text { alcoholic as a function of neurotransmitter } \\
\text { restoration: a pilot study. The International } \\
\text { journal of the addictions 23: } 991-8 \text {. }\end{array}$ & $\begin{array}{l}\text { First small clinical trial of SAAVE (precursor amino acid loading and enkephalinase } \\
\text { inhibition -earliest version of NAAT). Designed to elevate levels of enkephalin(s), } \\
\text { serotonin, catecholamines, and GABA, thought to be deficient in alcoholics. Compared } \\
\text { to controls those who took SAAVE had lower building up to drink score, required no } \\
\text { PRN benzodiazepines, ceased having tremors } 24 \text { hours earlier, and had less depression. }\end{array}$ \\
\hline
\end{tabular}




\begin{tabular}{|c|c|c|}
\hline & $\begin{array}{l}\text { Blum K, Trachtenberg MC, Elliott CE, et al. } \\
\text { Enkephalinase inhibition and precursor } \\
\text { amino acid loading improves inpatient } \\
\text { treatment of alcohol and polydrug abusers: } \\
\text { double-blind placebo-controlled study of } \\
\text { the nutritional adjunct SAAVE. Alcohol. 5(6): } \\
\text { 481-93. }\end{array}$ & $\begin{array}{l}\text { Double blind placebo controlled clinical trial of SAAVE of } 62 \text { people with Substance Use } \\
\text { Disorder (SUD). Results reduced stress as measured by skin conductance, improved } \\
\text { Physical and BESS (behavioral, emotional, social and spiritual) Scores, and had a six- } \\
\text { fold decrease in leaving Against Medical Advice (AMA) rates. }\end{array}$ \\
\hline & $\begin{array}{l}\text { Blum K, Allison D, Trachtenberg MC, et } \\
\text { al. Reduction of both drug hunger and } \\
\text { withdrawal against advice rate of cocaine } \\
\text { abusers in a } 30 \text { day inpatient treatment } \\
\text { program by the neuronutrient Tropamine. } \\
\text { Current Therapeutic Research 43: 1204- } \\
1214 \text {. }\end{array}$ & $\begin{array}{l}\text { Comparison of the effects of Tropamine }[\mathrm{T}] \text { - (amino acid and vitamin supplement), } \\
\text { SAAVE [S]-(a neuronutrient supplement) and no supplement [C] on a group of cocaine } \\
\text { abusers in a } 30 \text {-day hospital treatment program. AMA rate [C] 37.5\%, [S] } 26.6 \% \text {, and } \\
\text { [T] } 4.2 \% \text {. Tropamine decreased the AMA rate by significant reduction of drug hunger. }\end{array}$ \\
\hline \multirow[t]{2}{*}{1990} & $\begin{array}{l}\text { Brown RJ, Blum K, Trachtenberg, MC, } \\
\text { Neurodynamics of relapse prevention: a } \\
\text { neuronutrient approach to outpatient DUI } \\
\text { offenders. Psychoactive Drugs 22: 173-187. }\end{array}$ & $\begin{array}{l}\text { Relapse prevention using neuronutrients SAAVE and Tropamine in DUI offenders; } \\
\text { either alcohol or cocaine. Reduced relapse rates and enhanced recovery in 10-week } \\
\text { outpatient setting. After } 10 \text { months' recovery rate was SAAVE 73\% and Tropamine } \\
53 \% \text {. }\end{array}$ \\
\hline & $\begin{array}{l}\text { Blum K, Trachtenberg MC, Cook DW. } \\
\text { Neuronutrient effects on weight loss in } \\
\text { carbohydrate bingers; an open clinical trial. } \\
\text { Curr Ther Res.48: 217-233. }\end{array}$ & $\begin{array}{l}\text { Examine the effects of PCAL-103 (NAAT) on compulsive eating and weight loss in } 27 \\
\text { outpatients attending a supervised diet-controlled treatment program. The PCAL-103 } \\
\text { average weight loss was } 26.96 \text { lbs vs } 10.2 \text { lbs in the control group. Relapse } 18.2 \% \text { in the } \\
\text { PCAL-103 group vs } 81.8 \% \text { in the control group. }\end{array}$ \\
\hline 1996 & $\begin{array}{l}\text { Cold JA, NeuRecover-SATM in the Treatment } \\
\text { of Cocaine Withdrawal and Craving: A Pilot } \\
\text { Study. Clinical Drug Investigation. 12(1):1-7, }\end{array}$ & $\begin{array}{l}\text { Small preliminary study of efficacy of NeuRecover-SATM (formerly Tropamine+TM) } \\
\text { in the treatment of cocaine withdrawal and craving. Cocaine craving decreased } \\
\text { significantly in the NeuRecover-SATM group. }\end{array}$ \\
\hline \multirow[t]{2}{*}{1997} & $\begin{array}{l}\text { DeFrance JF, Hymel C, Trachtenberg MC, et } \\
\text { al. Enhancement of attention processing by } \\
\text { Kantroll in healthy humans: a pilot study. } \\
\text { Clinical Electroencephalography 28: 68-75. }\end{array}$ & $\begin{array}{l}\text { Cognitive processing speeds in normal young adult volunteers were measured before } \\
\text { and after 28-30 days of supplementation with a combination of amino acids (NAAT), } \\
\text { vitamins and minerals. Cognitive processing speeds were enhanced by a statistically } \\
\text { significant amplitude of the P300 component of the Event Related Potentials (ERPs). } \\
\text { FOCUS IMPROVED }\end{array}$ \\
\hline & $\begin{array}{l}\text { Blum K, Cull JG, Chen TJH, et al. Clinical } \\
\text { evidence for effectiveness of Phencal }{ }^{\mathrm{M}} \\
\text { in maintaining weight loss in an open- } \\
\text { label, controlled, 2-year study. Current } \\
\text { Therapeutic Research 55(10) 745-763. }\end{array}$ & $\begin{array}{l}\text { Of } 247 \text { Outpatients in a very-low-calorie fasting program } 130 \text { who were having } \\
\text { difficulty attaining their desired weight or maintaining their desired weight constituted } \\
\text { the experimental group who took PhenCal }{ }^{T M} \text { and the rest } 117 \text { took vitamins } 117 \text { were } \\
\text { the control group. The PhenCal }{ }^{T} \text { group compared to the control lost twice as much } \\
\text { weight, regained } 14.7 \% \text { of the weight while the control group regained } 41.7 \% \text {, decrease } \\
\text { in food cravings for females } 70 \% \text { and males } 63 \% \text {, and decreased in binge eating for } \\
\text { females } 66 \% \text { and males } 41 \% \text {. }\end{array}$ \\
\hline 2001 & $\begin{array}{l}\text { Ross J. Amino-acid precursor and } \\
\text { enkephalinase inhibition therapy: evidence } \\
\text { for effectiveness in treatment of "Reward } \\
\text { Deficiency Syndrome (RDS) with particular } \\
\text { emphasis on eating disorders. Mol } \\
\text { Psychiatry. Feb; 6(1 Suppl 1):S1-8. }\end{array}$ & $\begin{array}{l}\text { Preliminary evaluation of six randomly selected former eating disordered female } \\
\text { clients (three were also chemically dependent), contacted at } 9 \text { months and } 3 \text { years } \\
\text { of treatment with amino-acid precursor and enkephalinase inhibition therapy. All } 6 \\
\text { reported initial benefit, one relapsed at } 6 \text { months the other } 5 \text { all sustained, and in some } \\
\text { cases exceeded expectations. } 98 \% \text { of } 100 \text { patients similarly treated and evaluated } \\
\text { reported significant improvement in both mood and reduced substance craving. }\end{array}$ \\
\hline 2004 & $\begin{array}{l}\text { Chen TJ; Blum K, Payte, Jt, et al. Narcotic } \\
\text { antagonists in drug dependence: pilot } \\
\text { study showing enhancement of compliance } \\
\text { with SYN-10, amino-acid precursors and } \\
\text { enkephalinase inhibition therapy. Medical } \\
\text { Hypotheses } 63 \text { (3): 538-48. }\end{array}$ & $\begin{array}{l}\text { A combination of Trexan (a narcotic antagonist) and amino-acids was use to detoxify } \\
\text { either methadone or heroin addicts. Results were dramatic in terms of significantly } \\
\text { enhancing compliance to continue taking Trexan. Trexan alone for rapid detoxification } \\
\text { the average number of days of compliance calculated on } 1000 \text { patients is } 37 \text { days. } \\
12 \text { subjects tested, receiving both the Trexan and amino-acid therapy taking the } \\
\text { combination for an average of } 262 \text { days. Suggests coupling amino-acid therapy and } \\
\text { enkephalinase inhibition, while blocking the delta-receptors with a pure narcotic } \\
\text { antagonist as a novel method to induce rapid detox in chronic methadone patients and } \\
\text { prevent relapse, and testing this hypothesis with the sublingual combination of the } \\
\text { partial opiate mu receptor agonist buprenorphine. }\end{array}$ \\
\hline
\end{tabular}




\begin{tabular}{|c|c|c|}
\hline 2006 & $\begin{array}{l}\text { Blum K, Chen TJ, Meshkin B, et al. } \\
\text { Reward deficiency syndrome in obesity: } \\
\text { a preliminary cross-sectional trial with a } \\
\text { Genotrim variant. Adv Ther. } 2006 \text { Nov- } \\
\text { Dec;23(6):1040-51. }\end{array}$ & $\begin{array}{l}\text { Consumption of large quantities of alcohol or carbohydrates (carbohydrate bingeing) } \\
\text { stimulates production and usage of dopamine within the brain. Obesity is due to the } \\
\text { need to make up for inadequate dopaminergic activity in the reward center of the } \\
\text { brain. This has been called reward deficiency syndrome (RDS) used to categorize } \\
\text { such genetic biologic influences on behavior. RDS must be addressed at the same } \\
\text { time as behavioral modifications are implemented to adequately treat obese patients. } \\
\text { In this small observational trial; } 24 \text { individuals completed a survey on which they } \\
\text { documented } 15 \text { categories of benefit during their experience with a GenoTrim a NAAT } \\
\text { formulation customized to DNA. Statistical analysis of the survey results demonstrated } \\
\text { that stress reduction lead to improved sleep, enhanced energy, and improved focus and } \\
\text { performance, reduced appetite, loss of unwanted weight, decreased body inches, and } \\
\text { enhanced well-being. }\end{array}$ \\
\hline \multirow{4}{*}{2007} & $\begin{array}{l}\text { Chen TJ, Blum K, Waite RL, et al. Gene } \backslash \\
\text { Narcotic Attenuation Program attenuates } \\
\text { substance use disorder, a clinical subtype of } \\
\text { reward deficiency syndrome. Advances in } \\
\text { Therapy 24: 402-414. }\end{array}$ & $\begin{array}{l}\text { 1-year prospective study that evaluated the effects of taking Haveos (SynaptamineTM) } \\
\text { on } 61 \text { compliant patients in a comprehensive outpatient clinical program. Results after } \\
12 \text { weeks include significant decrease in craving. Results after } 1 \text { year include building } \\
\text { up to relapse scores and ability to refrain from drug-seeking behavior both significantly } \\
\text { improved. The dropout rate for alcohol users } 7 \% \text { and psychostimulant users } 73 \%\end{array}$ \\
\hline & $\begin{array}{c}\text { Blum K, Chen TJH, Downs BW, et al. } \\
\text { Synaptamine (SG8839),TM An Amino-Acid } \\
\text { Enkephalinase Inhibition Nutraceutical } \\
\text { Improves Recovery of Alcoholics, A Subtype } \\
\text { of Reward Deficiency Syndrome (RDS). } \\
\text { Trends in Applied Sciences Research } 2 \text { (3): } \\
\text { 132-138. }\end{array}$ & $\begin{array}{l}\text { In an open clinical study Amino-Acid Enkephalinase Inhibition Nutraceutical } \\
\text { improved symptomatology of } 600 \text { recovering Alcoholics. Emotional and behavioral } \\
\text { recovery scores significantly improved after administration of oral and intravenous } \\
\text { Synaptamine. Mean reductions for craving, depression, anxiety, anger, fatigue, lack of } \\
\text { energy and crisis were all significantly greater than } 50 \%(\mathrm{p}<0.001) \text {. }\end{array}$ \\
\hline & $\begin{array}{l}\text { Chen TJH , Blum K, Kaats G, et al. Chromium } \\
\text { Picolinate (Crp) A putative Anti-Obesity } \\
\text { Nutrient Induces Changes In Body } \\
\text { Composition As Function Of The Taq1 } \\
\text { Dopamine D2 Receptor Gene. Gene Ther } \\
\text { Molboil 11; 161-170. }\end{array}$ & $\begin{array}{l}\text { Chromium Picolinate (CrP) was tested against placebo in groups of obese patients } \\
\text { tested for the Taq1 Dopamine D2 Receptor Gene. In carriers of the DRD2 A2 genotype } \\
\text { weight loss and other changes in body composition were significant. They were not } \\
\text { significant for patients with the A1/A1 or A1/A2 allele. These results suggest that the } \\
\text { dopaminergic system, specifically the density of the D2 receptors, confers a significant } \\
\text { differential therapeutic effect of CrP in terms of weight loss and change in body fat. }\end{array}$ \\
\hline & $\begin{array}{l}\text { Blum K, Chen TJH, Williams L, et al. A short } \\
\text { term pilot open label study to evaluate } \\
\text { efficacy and safety of LG839, a customized } \\
\text { DNA directed nutraceutical in obesity: } \\
\text { Exploring Nutrigenomics. Gene Therapy and } \\
\text { Molecular Biology Vol 12, page 371-382. }\end{array}$ & $\begin{array}{l}\text { Preliminary investigational study of evaluate the impact of polymorphisms of five } \\
\text { candidate genes on treatment for obesity with NAAT. The formula for each patient was } \\
\text { customized based on their genetic results. }\end{array}$ \\
\hline \multirow[b]{2}{*}{2008} & $\begin{array}{l}\text { Blum K, Chen AL, Chen TJ, et al. LG839: } \\
\text { anti-obesity effects and polymorphic gene } \\
\text { correlates of reward deficiency syndrome. } \\
\text { Advances in Therapy } 25 \text { (9): 894-913. }\end{array}$ & $\begin{array}{l}\text { A novel experimental DNA-customized nutraceutical, LG839. Polymorphic correlates } \\
\text { were obtained for a number of genes (LEP, PPAR-gamma2, MTHFR, 5-HT2A, and } \\
\text { DRD2 genes) with positive clinical parameters tested in this study. Significant results } \\
\text { were observed for weight loss, sugar craving reduction, appetite suppression, snack } \\
\text { reduction, reduction of late night eating, increased energy etc. Only the DRD2 gene } \\
\text { polymorphism (A1 allele) had a significant Pearson correlation with days on treatment. }\end{array}$ \\
\hline & $\begin{array}{l}\text { Blum K, Chen TJH, Chen ALC, et al. Dopamine } \\
\text { D2 Receptor Taq A1 allele predicts treatment } \\
\text { compliance of LG839 in a subset analysis of } \\
\text { pilot study in the Netherlands. Gene Therapy } \\
\text { Molecular Biology } 12,129-140 .\end{array}$ & $\begin{array}{l}\text { Hypothesized that genotyping certain known candidate genes would provide DNA- } \\
\text { individualized customized nutraceuticals that may have significant influence on body } \\
\text { re-composition by countering various genetic traits.Genotyped for the dopamine } \\
\text { D2 receptor (DRD2), methylenetetrahydrofolate reductase (MTHFR), serotonin } \\
\text { receptor (5-HT2a), Peroxisome Proliferator Activated Receptor gamma (PPAR- } \gamma \text { ), and } \\
\text { Leptin (OB) genes. Systematically evaluated the impact of polymorphisms of these } \\
\text { five candidate genes as important targets for the development of a DNA-customized } \\
\text { nutraceutical LG839 [dl-phenylalanine, chromium, l-tyrosine other select amino-acids } \\
\text { and adaptogens] to combat obesity with special emphasis on body recomposition as } \\
\text { measured by Body Mass Index (BMI). In the } 41 \text { day period we found a trend in weight } \\
\text { loss whereby } 71.4 \% \text { of subjects lost weight. }\end{array}$ \\
\hline 2009 & $\begin{array}{c}\text { Blum K, Chen ALC, Chen TJH, et al. Putative } \\
\text { targeting of Dopamine D2 receptor function } \\
\text { in Reward Deficiency Syndrome (RDS) by } \\
\text { Synaptamine Complex } \\
\text { Clinical trial showing anti-anxiety effects. } \\
\text { Gene Therapy Molecular Biology 13, 214- } \\
230 .\end{array}$ & $\begin{array}{l}\text { Brain dopamine has been implicated as the so-called "anti-stress molecule." The } \\
\text { present study investigated anti-anxiety effects of Synaptamine Complex [KB220], a } \\
\text { dopaminergic activator, in a randomized double-blind placebo controlled study in } \\
\text { alcoholics and in polydrug abusers attending an in-patient chemical dependency } \\
\text { program. Patients receiving Synaptamine Complex [KB220] had a significantly reduced } \\
\text { stress response as measured by SCL, compared to patients receiving placebo. }\end{array}$ \\
\hline
\end{tabular}




\begin{tabular}{|c|c|c|}
\hline \multirow{3}{*}{2010} & $\begin{array}{l}\text { Braverman ER, Braverman D, Acrui V, et al. } \\
\text { Targeting Noradrenergic and dopaminergic } \\
\text { Mechanistic Sites, Hormonal Deficiency } \\
\text { Repletion Therapy and Exercise: A case } \\
\text { report. The American Journal of Bariatric } \\
\text { Medicine. } 25(2) 18-28,2010 .\end{array}$ & $\begin{array}{l}\text { Case study evaluating sustained weight loss with Synaptamine complex in conjunction } \\
\text { with Diethypropion (Tenuate } ₫ \text { ), hormonal repletion therapy; use of the Rainbow } \\
\text { Diet } ₫ \text { and light exercise. After one year, the } 58 \text { year old patient's BMT decreased } \\
\text { from } 32 \text { to } 25.4 \mathrm{~kg} / \mathrm{m} 2 \text { representing a } 6.9 \mathrm{~kg} / \mathrm{m} 2 \text { reduction.His body fat composition } \\
\text { decreased from } 36.91 \% \text { to } 17.8 \% \text { as measured by the Hologic DEXA scanner. }\end{array}$ \\
\hline & $\begin{array}{l}\text { Miller DK, Bowirrat A, Manka M, et al. } \\
\text { Acute intravenous synaptamine complex } \\
\text { variant KB220 } 0^{\mathrm{TM}} \text { "normalizes" neurological } \\
\text { dysregulation in patients during } \\
\text { protracted abstinence from alcohol and } \\
\text { opiates as observed using quantitative } \\
\text { electroencephalographic and genetic } \\
\text { analysis for reward polymorphisms: part } \\
\text { 1, pilot study with } 2 \text { case reports. Postgrad } \\
\text { Med. Nov; } 122(6): 188-213 .\end{array}$ & $\begin{array}{l}\text { Intravenous Synaptamine complex in protracted abstinence from alcohol and } \\
\text { opiates analyzed by qEEG. Report that the qEEGs of an alcoholic and a heroin abuser } \\
\text { with existing abnormalities (i.e., widespread theta and widespread alpha activity, } \\
\text { respectively) during protracted abstinence are significantly normalized by the } \\
\text { administration of } 1 \text { intravenous dose of Synaptamine Complex Variant KB220 } 20^{\mathrm{TM}}\end{array}$ \\
\hline & $\begin{array}{l}\text { Blum K, Chen TJ, Morse S, et al. Overcoming } \\
\text { qEEG abnormalities and reward gene } \\
\text { deficits during protracted abstinence } \\
\text { in male psychostimulant and polydrug } \\
\text { abusers utilizing putative dopamine } \mathrm{D}_{2} \\
\text { agonist therapy: part 2. Postgrad. Med. Nov; } \\
\text { 122(6):214-26. }\end{array}$ & $\begin{array}{l}\text { Protracted Abstinence in Psychostimulant abusers. qEEG analysis in DRD2 A1 allele } \\
\text { carriers. Compared to placebo -Synaptose Complex KB220Z } \\
\text { regulation of induced positive } \\
\text { dysregulated electrical activity of the brain in these addicts. }\end{array}$ \\
\hline 2011 & $\begin{array}{l}\text { Blum K, Stice E, Liu Y, et al. “Dopamine } \\
\text { Resistance" in brain reward circuitry } \\
\text { as a function of DRD2 gene receptor } \\
\text { polymorphisms in RDS: Synaptamine } \\
\text { complex variant (KB220) induced } \\
\text { "Dopamine Sensitivity" and enhancement } \\
\text { of happiness. XIX World Congress of } \\
\text { Psychiatric Genetics, September 10-14th. } \\
\text { Washington DC. }\end{array}$ & $\begin{array}{l}\text { Synaptamine Complex Variant [KB220] }{ }^{\mathrm{TM}} \text { as an activator of the meso-limbic system } \\
\text { and administration significantly reduces or "normalizes" aberrant electrophysiological } \\
\text { parameters of the reward circuitry site. Based on our QEEG studies presented herein } \\
\text { we cautiously suggest that long-term activation of dopaminergic receptors (i.e., DRD2 } \\
\text { receptors) will result in proliferation of D2 receptors leading to enhanced "dopamine } \\
\text { sensitivity" and an increased sense of happiness. Oral KB220 showed an increase } \\
\text { of Alpha activity and an increase low Beta activity similar to 10-20 sessions with } \\
\text { Neurofeedback. }\end{array}$ \\
\hline \multirow{3}{*}{2012} & $\begin{array}{l}\text { Chen D, Liu Y, He W, et al. Neurotransmitter- } \\
\text { precursor-supplement Intervention for } \\
\text { Detoxified Heroin Addicts. Huazhong } \\
\text { University of Science and Technology and } \\
\text { Springer-Verlag Berlin Heidelberg [Med Sci } \\
\text { 32(3):422-427,2012 }\end{array}$ & $\begin{array}{l}\text { This study examined the effects of combined administration of tyrosine, lecithin, } \\
\text { L-glutamine and L-5-hydroxytryptophan (5-HTP) on heroin withdrawal syndromes and } \\
\text { mental symptoms in detoxified heroin addicts. The results showed that the insomnia } \\
\text { and withdrawal scores were significantly improved over time in participants in the } \\
\text { intervention group as compared with those in the control group. A greater reduction } \\
\text { in tension-anxiety, depression-dejection, anger-hostility, fatigue-inertia and total mood } \\
\text { disturbance, and a greater increase in their vigor-activity symptoms were found at day } \\
6 \text { in the intervention group than in the control placebo group }\end{array}$ \\
\hline & $\begin{array}{l}\text { Miller M, Chen ALC, Stokes SD, et al. Early } \\
\text { Intervention of Intravenous KB220IV- } \\
\text { Neuroadaptagen Amino-Acid Therapy } \\
\text { (NAAT) }{ }^{\mathrm{TM}} \text { Improves Behavioral Outcomes in } \\
\text { a Residential Addiction Treatment Program: } \\
\text { A Pilot Study. Journal of Psychoactive Drugs } \\
\quad \text { (in press December issue 2012). }\end{array}$ & $\begin{array}{l}\text { In } 129 \text { patients a combination of IV and oral NAAR therapy (generic KB220) were } \\
\text { assessed for Chronic Abstinence Symptom Severity (CASS) Scale over a 30-day period. } \\
\text { Three scales were constructed based on this factor analysis: Emotion, Somatic, and } \\
\text { Cognitive. All three scales showed significant improvement ( } \mathrm{P}=0.00001) \text { from pre-to } \\
\text { post -treatments: } \mathrm{t}=19.1 \text { for Emption, } \mathrm{t}=16.1 \text { for Somatic, and } \mathrm{t}=14.9 \text { for impaired } \\
\text { cognitive. A two-year follow-up in a subset of } 23 \text { patients showed: } 21(91 \%) \text { were } \\
\text { sober at } 6 \text { months with } 19(82 \%) \text { having no relapse; } 19(82 \% \text { were sober at one year } \\
\text { with } 18(78 \%) \text { having no relapse; } 21(91 \%) \text { were sober at two-years post-treatment } \\
\text { with } 16(70 \%) \text { having no relapse. Note: these results of cause do not reflect any other } \\
\text { recovery skills utilized by the patients including } 12 \text { steps program and Fellowship. }\end{array}$ \\
\hline & $\begin{array}{l}\text { Blum K, Miller M, Miller D, et al. } \\
\text { Neurogenetics and Nutrigenomics of } \\
\text { Neuro-Nutrient Therapy for Reward } \\
\text { Deficiency Syndrome: Clinical Ramifications } \\
\text { and Pitfalls. Nutrients. } 2012 \text { Nov 27. doi: } \\
\text { 10.4172/2155-6105.1000139 }\end{array}$ & $\begin{array}{l}\text { New Definition of Addiction by American Society of Addiction Medicine (ASAM) } \\
\text { is based on concepts related to Reward Deficiency Syndrome(RDS). Brain Reward } \\
\text { Cascade (BRC) Impairment leads to aberrant craving behavior and other behaviors } \\
\text { such as Substance Use Disorder (SUD) due to a "hypodopaminergic" trait/state. Any } \\
\text { impairment due to either genetics or environmental influences on this cascade will } \\
\text { result in a reduced amount of dopamine release in the brain reward site. After over } \\
\text { four decades of development, neuro-nutrient therapy has provided important clinical } \\
\text { benefits when appropriately utilized. }\end{array}$ \\
\hline
\end{tabular}




\begin{tabular}{|c|c|c|}
\hline 2013 & $\begin{array}{c}\text { Blum K, Oscar-Berman M, Femino J, et } \\
\text { al. Withdrawal from Buprenorphine/ } \\
\text { Naloxone and Maintenance with a Natural } \\
\text { Dopaminergic Agonist: A Cautionary Note. } \\
\text { J Addict Res Ther. 2013 Apr 23;4(2). doi: } \\
\text { 10.4172/2155-6105.1000146. }\end{array}$ & $\begin{array}{l}\text { A case study of a } 35 \text { year old female in the film industry with a history of chronic pain } \\
\text { from reflex sympathetic dystrophy and fibromyalgia. Total monthly prescription costs } \\
\text { including supplemental benzodiazepines, hypnotics and stimulants exceeded } \$ 50,000 \text {. } \\
\text { Withdrawal symptoms were carefully documented when she precipitously stopped } \\
\text { taking buprenorphine/naloxone. At } 432 \text { days post Suboxone }{ }^{\circledR} \text { withdrawal the patient } \\
\text { is being maintained on KB220Z, has been urine tested and is opioid free. Genotyping } \\
\text { data revealed a moderate genetic risk for addiction showing a hypodopaminergic trait. }\end{array}$ \\
\hline \multirow{3}{*}{2015} & $\begin{array}{l}\text { McLaughlin T, Blum K, Oscar-Berman M, } \\
\text { et al. Putative dopamine agonist (KB220Z) } \\
\text { attenuates lucid nightmares in PTSD } \\
\text { patients: Role of enhanced brain reward } \\
\text { functional connectivity and homeostasis } \\
\text { redeeming joy. J Behav Addict. } 2015 \text { Jun; } \\
\text { 4(2):106-15. doi: } 10.1556 / 2006.4 .2015 .008 .\end{array}$ & $\begin{array}{l}\text { Lucid dreams may be associated with psychiatric conditions, including Post-Traumatic } \\
\text { Stress Disorder (PTSD) and Reward Deficiency Syndrome-associated diagnoses. We } \\
\text { present two cases of dramatic alleviation of terrifying lucid dreams in patients with } \\
\text { PTSD. The medication visit notes reveal changes in the frequency, intensity and nature } \\
\text { of these dreams after the complex putative dopamine agonist KB220Z was added to } \\
\text { the first patient's regimen. The second PTSD patient, who had suffered from lucid } \\
\text { nightmares, was administered KB220Z to attenuate methadone withdrawal symptoms } \\
\text { and incidentally reported dreams full of happiness and laughter. }\end{array}$ \\
\hline & $\begin{array}{l}\text { McLaughlin T, Blum K, Oscar-Berman M, et } \\
\text { al. Using the Neuroadaptagen KB200z }{ }^{\mathrm{TM}} \text { to } \\
\text { Ameliorate Terrifying, Lucid Nightmares } \\
\text { in RDS Patients: the Role of Enhanced, } \\
\text { Brain-Reward, Functional Connectivity and } \\
\text { Dopaminergic Homeostasis. J Reward Defic } \\
\text { Syndr. 2015;1(1):24-35. }\end{array}$ & $\begin{array}{l}\text { Lucid dreams could be un-pleasant or terrifying, at least in the context of patients, who } \\
\text { also exhibit characteristics of Reward Deficiency Syndrome (RDS) and Posttraumatic } \\
\text { Stress Disorder (PTSD). We present eight clinical cases, with known substance abuse, } \\
\text { childhood abuse and diagnosed PTSD/RDS. The administration of a putative dopamine } \\
\text { agonist, KB200Z }{ }^{\text {TM }} \text {, was associated with the elimination of unpleasant and/or terrifying, } \\
\text { lucid dreams in } 87.5 \% \text { of the cases presented, whereas one very heavy cocaine } \\
\text { abuser showed a minimal response. These results required the continuous use of this } \\
\text { nutraceutical. If these results in a small number of patients are indeed confirmed we } \\
\text { may have found a frontline solution to a very perplexing and complicated symptom } \\
\text { known as lucid dreams. }\end{array}$ \\
\hline & $\begin{array}{l}\text { Blum K, Liu Y, Wang W, et al. rsfMRI } \\
\text { effects of KB220Z } \\
\text { reward circuitry of abstinent genotyped } \\
\text { heroin addicts. Postgrad Med. } 2015 \\
\text { Mar;127(2):232-41. }\end{array}$ & $\begin{array}{l}\text { Willuhn et al. reported that cocaine use and even non-substance-related addictive } \\
\text { behavior increases as dopaminergic function is reduced. Chronic cocaine exposure } \\
\text { has been associated with decreases in D2/D3 receptors and was also associated with } \\
\text { lower activation of cues in occipital cortex and cerebellum, in a recent PET study by } \\
\text { Volkow's et al. KB220Z induced an increase in BOLD activation in caudate-accumbens- } \\
\text { dopaminergic pathways compared to placebo following 1-hour acute administration in } \\
\text { abstinent heroin addicts. Increased functional connectivity was observed in a putative } \\
\text { network that included the dorsal anterior cingulate, medial frontal gyrus, nucleus } \\
\text { accumbens, posterior cingulate, occipital cortical areas, and cerebellum. Results } \\
\text { suggest a putative anti-craving/anti-relapse role of KB220Z in addiction by direct or } \\
\text { indirect dopaminergic interaction. }\end{array}$ \\
\hline 2016 & $\begin{array}{l}\text { McLaughlin T, Febo M, Badgaiyan RD, Barh } \\
\text { D, Dushaj K, et al. 2016. KB220Z } \\
\text { Dopamine Regulator Associated with the } \\
\text { Protracted, Alleviation of Terrifying Lucid } \\
\text { Dreams. Can We Infer Neuroplasticity- } \\
\text { induced Changes in the Reward Circuit? J } \\
\text { Reward Defic Syndr Addict Sci 2(1): 3-13. }\end{array}$ & $\begin{array}{l}\text { The four patients initially reported a gradual but, then, complete amelioration of their } \\
\text { long-term, terrifying, lucid dreams, while taking KB220Z. The persistent amelioration } \\
\text { of these dreams continued for up to } 12 \text { months, after - KB220Z. These particular cases } \\
\text { raise the scientific possibility that KB200Z increases both dopamine stability as well } \\
\text { as functional connectivity between networks of brain reward circuitry in both rodents } \\
\text { and humans. In order to attempt to understand the possibility of neuroplasticity, } \\
\text { we evaluated the effect of KB220Z in non-opioid-addicted rats utilizing functional } \\
\text { Magnetic Resonance Imaging methodology. While we cannot make a definitive claim } \\
\text { because rat brain functional connectivity may not be exactly the same as humans, } \\
\text { it does provide some interesting clues. We did find following seeding of the dorsal } \\
\text { hippocampus, enhanced connectivity volume across several Regions of Interest (ROI), } \\
\text { with the exception of the pre- frontal cortex. Interestingly, the latter region is only } \\
\text { infrequently activated in lucid human dreaming, when the dreamer reports that he/she } \\
\text { had the thought that they were dreaming during the lucid dream. }\end{array}$ \\
\hline
\end{tabular}




\begin{tabular}{|c|c|c|}
\hline 2016 & $\begin{array}{l}\text { Bruce Steinberg, Kenneth Blum, Thomas } \\
\text { McLaughlin, Joel Lubar, Marcelo Febo } \\
\text { et al. Low-Resolution Electromagnetic } \\
\text { Tomography (LORETA) of changed Brain } \\
\text { Function Provoked by Pro-Dopamine } \\
\text { Regulator (KB220z) in one Adult ADHD case. } \\
\text { Open J of Clin. Med. Case Rep. 2;(11) } 2016\end{array}$ & $\begin{array}{l}\text { Attention Deficit-Hyperactivity Disorder (ADHD) often continues into adulthood. } \\
\text { Recent neuroimaging studies found lowered baseline dopamine tone in the brains of } \\
\text { affected individuals that may place them at } \\
\text { risk for Substance Use Disorder (SUD). This is an observational case study of the } \\
\text { potential for novel management of Adult ADHD with a non-addictive glutaminergic- } \\
\text { dopaminergic optimization complex KB200z. Low-resolution electromagnetic } \\
\text { tomography (LORETA) was used to evaluate the effects of } \\
\text { KB220z on a 72-year-old male with ADHD, at baseline and one hour following } \\
\text { administration. The resultant z-scores, averaged across Eyes Closed, Eyes Open and } \\
\text { Working Memory conditions, increased } \\
\text { for each frequency band, in the anterior, dorsal and posterior cingulate regions, as } \\
\text { well as the right dorsolateral prefrontal cortex during Working Memory, with KB220z. } \\
\text { These scores are consistent with other human and animal neuroimaging studies that } \\
\text { demonstrated increased connectivity volumes in reward circuitry and may offer a } \\
\text { new approach to ADHD treatment. However, larger randomized trials to confirm these } \\
\text { results are required. }\end{array}$ \\
\hline 2016 & $\begin{array}{l}\text { Bruce Steinberg, Kenneth Blum, Thomas } \\
\text { McLaughlin, Joel Lubar, Marcelo Febo } \\
\text { et al. Low-Resolution Electromagnetic } \\
\text { Tomography (LORETA) of changed Brain } \\
\text { Function Provoked by Pro-Dopamine } \\
\text { Regulator (KB220z) in one Adult ADHD case. } \\
\text { Open J of Clin. Med. Case Rep. 2;(11) } 2016\end{array}$ & $\begin{array}{l}\text { Attention Deficit-Hyperactivity Disorder (ADHD) often continues into adulthood. } \\
\text { Recent neuroimaging studies found lowered baseline dopamine tone in the brains of } \\
\text { affected individuals that may place them at } \\
\text { risk for Substance Use Disorder (SUD). This is an observational case study of the } \\
\text { potential for novel management of Adult ADHD with a non-addictive glutaminergic- } \\
\text { dopaminergic optimization complex KB200z. Low-resolution electromagnetic } \\
\text { tomography (LORETA) was used to evaluate the effects of } \\
\text { KB220z on a 72-year-old male with ADHD, at baseline and one hour following } \\
\text { administration. The resultant z-scores, averaged across Eyes Closed, Eyes Open and } \\
\text { Working Memory conditions, increased } \\
\text { for each frequency band, in the anterior, dorsal and posterior cingulate regions, as } \\
\text { well as the right dorsolateral prefrontal cortex during Working Memory, with KB220z. } \\
\text { These scores are consistent with other human and animal neuroimaging studies that } \\
\text { demonstrated increased connectivity volumes in reward circuitry and may offer a } \\
\text { new approach to ADHD treatment. However, larger randomized trials to confirm these } \\
\text { results are required. }\end{array}$ \\
\hline
\end{tabular}

\section{Conclusion}

Recently the hypothesis [39-43] that KB220Z would enhance resting connectivity patterns between reward and cognitive brain regions was tested in placebo-controlled rsfMRI experiments in the rat. Additionally, qEEG studies in humans found that KB220Z modulates theta power in the anterior cingulate cortex $[44,45]$. Double-blind controlled studies and others [37,46-48] have demonstrated positive effects on both craving attenuation and relapse prevention [48-50] and enhanced compliance to KB220Z treatment was significant in obese carriers of the D2 receptors A1 allele vs. carriers of the usual complement of DA D2 receptors $[51,52]$. The rationale for evaluating KB220Z in the present article application is the evidence of clinical benefit KB220Z can give by epigenetically changing the neuro-mechanisms involved in producing dopamine homeostasis [53]. Based on this research and current literature new strategies to treat RDS are needed. The traditionally used therapeutic agents have failed to address the reduced connectivity patterns now seen in many addictions and have had limited success in relapse prevention and effective recovery from psychoactive substance abuse $[4,54]$. This concept would enable genetic testing and precise treatment of genetic and epigenetic deficits with formulations of KB220 [55,56]. Recovery and good health would be the goal of this SMART, holistic program design, based on this extensive research in a diverse but stable population [57]. In a diverse but stable population like African- Americans as well as other minority groups showing high genetic risk for all RDS behaviors.

\section{References}

1. Blum K, Oscar-Berman M, Dinubile N, Giordano J, Braverman ER, et al. (2013) Coupling Genetic Addiction Risk Score (GARS) with Electrotherapy: Fighting Iatrogenic Opioid Dependence. J Addict Res Ther 4(163).

2. Zsolt Demetrovics, Róbert Urbán, K Blum (2016) Reward Deficiency Syndrome and Addictive Disorders. Hungary $4^{\text {th }}$ International Conference on Pathological Gambling and Other Behavioural Addictions, Europe.

3. Blum K, Han D, Femino J, Smith DE, Saunders S, et al. (2014) Systematic evaluation of "compliance" to prescribed treatment medications and "abstinence" from psychoactive drug abuse in chemical dependence programs: data from the comprehensive analysis of reported drugs. PLoS One 9(9): e104275.

4. Blum K, Febo M, Fahlke C, Archer T, Berggren U, et al. (2015) Hypothesizing Balancing Endorphinergic and Glutaminergic Systems to Treat and Prevent Relapse to Reward Deficiency Behaviors: 


\section{Global Journal of Addiction \& Rehabilitation Medicine}

Coupling D-Phenylalanine and N-Acetyl-L-Cysteine (NAC) as a Novel Therapeutic Modality. Clin Med Rev Case Rep 2(8).

5. Blum K, Sheridan PJ, Wood RC, Braverman ER, Chen TJ, et al. (1996) The D2 dopamine receptor gene as a determinant of reward deficiency syndrome. J R Soc Med 89(7): 396-400.

6. Blum K, Braverman ER, Holder JM, Lubar JF, Monastra VJ, et al. (2000) Reward deficiency syndrome: a biogenetic model for the diagnosis and treatment of impulsive, addictive, and compulsive behaviors. J Psychoactive Drugs 32(i-iv): 1-112.

7. Blum K, Thanos PK, Badgaiyan RD, Febo M, Oscar-Berman M, et al. (2015) Neurogenetics and gene therapy for reward deficiency syndrome: are we going to the Promised Land? Expert Opin Biol Ther 15(7): 973-85.

8. Comings DE, Blum K (2000) Reward deficiency syndrome: genetic aspects of behavioral disorders. Prog Brain Res 126: 325-341.

9. Blum K, Oscar-Berman M, Giordano J, Downs B, Simpatico T, et al (2012) Neurogenetic Impairments of Brain Reward Circuitry Links to Reward Deficiency Syndrome (RDS): Potential Nutrigenomic Induced Dopaminergic Activation. J Genet Syndr Gene Ther 3(4).

10. Blum K, Febo M, Badgaiyan RD, Demetrovics Z, Simpatico T, et al. (2016) Common Neurogenetic Diagnosis and Meso-Limbic Manipulation of Hypodopaminergic Function in Reward Deficiency Syndrome (RDS) Changing the Recovery Landscape. Curr Neuropharmacol 15(1): 184194.

11. Blum K, Futterman S, Wallace JE, Schwertner HA (1977) Naloxoneinduced inhibition of ethanol dependence in mice. Nature 265(5589): 49-51.

12. Blum K, Gardner E, Oscar-Berman M, Gold M (2012) "Liking" and "Wanting" Linked to Reward Deficiency Syndrome (RDS) Hypothesizing Differential Responsivity in Brain Reward Circuitry. Curr Pharm Des 18(1): 113-118.

13. K Blum, J Payne (1990) Alcohol \& The Addictive Brain. The Free Press Simon \& Schuster, New York, USA.

14. Blum K, Noble EP, Sheridan PJ, Montgomery A, Ritchie T, et al. (1990) Allelic association of human dopamine D2 receptor gene in alcoholism. JAMA 263(15): 2055-2060.

15. Noble EP, Blum K, Ritchie T, Montgomery A, Sheridan PJ (1991) Allelic association of the D2 dopamine receptor gene with receptor-binding characteristics in alcoholism. Arch Gen Psychiatry 48(7): 648-54.

16. K. Blum and G. P. Kozlowski (1990) Ethanol and neuromodulators interaction: a cascade model of reward. In: Alcohol and Behavior. (Eds.) H Ollat, S. Parvez \& H Parvez VSP Press Utrecht, The Netherlands, USA

17. Blum K, Febo M, Thanos PK, Baron D, Fratantonio J, et al. (2015) Clinically Combating Reward Deficiency Syndrome (RDS) with Dopamine Agonist Therapy as a Paradigm Shift: Dopamine for Dinner? Mol Neurobiol 52(3): 1862-1869.

18. Blum K, Oscar-Berman M, Barh D, Giordano J, Gold M (2013) Dopamine Genetics and Function in Food and Substance Abuse. J Genet Syndr Gene Ther 4(121).

19. Sotomayor-Zárate R, Abarca J, Araya KA, Renard GM, Andrés ME, et al. (2015) Exposure to repeated immobilization stress inhibits cocaineinduced increase in dopamine extracellular levels in the rat ventral tegmental area. Pharmacol Res 101: 116-123.

20. Hill E, Han D, Dumouchel P, Dehak N, Quatieri T, et al. (2013) Long term Suboxone emotional reactivity as measured by automatic detection in speech. PLoS One 8(7).

21. Stice E, Yokum S, Blum K, Bohon C (2010) Weight gain is associated with reduced striatal response to palatable food. J Neurosci 30(39): 13105-13109.
22. Jenner P, Marsden CD (1987) Chronic pharmacological manipulation of dopamine receptors in brain. Neuropharmacology 26(7b): 931-940.

23. Bogomolova EV, Rauschenbach IY, Adonyeva NV, Alekseev AA, Faddeeva NV, et al. (2010) Dopamine down-regulates activity of alkaline phosphatase in Drosophila: the role of D2-like receptors. J Insect Physiol 56(9): 1155-1159.

24. Blum K, Chen TJ, Downs BW, Bowirrat A, Waite RL, et al. (2009) Neurogenetics of dopaminergic receptor supersensitivity in activation of brain reward circuitry and relapse: proposing "deprivationamplification relapse therapy" (DART). Postgrad Med 121(6): 176196.

25. Martinez D, Saccone PA, Liu F, Slifstein M, Orlowska D, et al. (2012) Deficits in dopamine $\mathrm{D}(2)$ receptors and presynaptic dopamine in heroin dependence: commonalities and differences with other types of addiction. Biol Psychiatry 71(3): 192-198.

26. Bonito-Oliva A, Södersten E, Spigolon G, Hu X, Hellysaz A (2016) Differential regulation of the phosphorylation of Trimethyl-lysine27 histone $\mathrm{H} 3$ at serine 28 in distinct populations of striatal projection neurons. Neuropharmacology 107: 89-99.

27. Blum K, Oscar-Berman M, Demetrovics Z, Barh D, Gold MS (2014) Genetic Addiction Risk Score (GARS): molecular neurogenetic evidence for predisposition to Reward Deficiency Syndrome (RDS) Mol Neurobiol 50(3): 765-96.

28. K Blum, BC Haberstic, A Smolen, D Han, Marlene Oscar-Berman, et al (2017) Genetic addiction risk score (GARS) predicts addiction severity index - MV alcohol and drug - Risk scores in a multi-center study. In, Submitted to PLOSONE.

29. Kenneth Blum, David Han, Mary Hauser, Bernard William Downs, John Giordano, et al. (2013) Neurogenetic Impairments of Brain Reward Circuitry Links to Reward Deficiency Syndrome (RDS) as evidenced by Genetic Addiction Risk Score (GARS): A case study. The IIOAB Journal 4(1): 4-9.

30. Kenneth Blum, B W Downs, Kristina Dushaj, Mona Li, Eric R Braverman et al. (2016) The Benefits of Customized DNA Directed Nutrition To Balance The Brain Reward Circuitry And Reduce Addictive Behaviors. Precis Med (Bangalore) 1(1): 18-33.

31. Blum K, Simpatico T, Badgaiyan RD, Demetrovics Z, Fratantonio J, et al. (2015) Coupling Neurogenetics (GARS) and a Nutrigenomic Based Dopaminergic Agonist to Treat Reward Deficiency Syndrome (RDS): Targeting Polymorphic Reward Genes for Carbohydrate Addiction Algorithms. J Reward Defic Syndr 1(2): 75-80.

32. McLaughlin T, Febo M, Badgaiyan RD, Barh D, Dushaj K, et al. (2016) KB220Z ${ }^{\mathrm{TM}}$ a Pro-Dopamine Regulator Associated with the Protracted Alleviation of Terrifying Lucid Dreams. Can We Infer Neuroplasticityinduced Changes in the Reward Circuit? J Reward Defic Syndr Addict Sci 2(1): 3-13.

33. Steinberg B, Blum K, McLaughlin T, Lubar J, Febo M, et al. (2016) Lowresolution electromagnetic tomography (LORETA) of changed brain function provoked by pro-dopamine regulator (KB220z) in one adult ADHD cases. Open J Clin Med Case Rep 2(11): 11-21.

34. Thanos PK, Katana JM, Ashby CR Jr, Michaelides M, Gardner EL, et al (2005) The selective dopamine D3 receptor antagonist SB-277011-A attenuates ethanol consumption in ethanol preferring (P) and nonpreferring (NP) rats. Pharmacol Biochem Behav 81(1): 190-197.

35. Thanos PK, Michaelides M, Umegaki H, Volkow ND (2008) D2R DNA transfer into the nucleus accumbens attenuates cocaine selfadministration in rats. Synapse 62(7): 481-486.

36. Boundy VA, Pacheco MA, Guan W, Molinoff PB (1995) Agonists and antagonists differentially regulate the high affinity state of the D2L receptor in human embryonic kidney 293 cells. Mol Pharmacol 48(5): 956-964. 
37. Blum K, Oscar-Berman M, Stuller E, Miller D, Giordano J, et al. (2012) Neurogenetics and Nutrigenomics of Neuro-Nutrient Therapy for Reward Deficiency Syndrome (RDS): Clinical Ramifications as a Function of Molecular Neurobiological Mechanisms. J Addict Res Ther 3(5): 139.

38. Blum K, Liu Y, Wang W, Wang Y, Zhang Y, et al. (2015) rsfMRI effects of KB220Z on neural pathways in reward circuitry of abstinent genotyped heroin addicts. Postgrad Med 127(2): 232-241.

39. Duong TQ, Yacoub E, Adriany G, Hu X, Ugurbil K, et al. (2002) Highresolution, spin-echo BOLD, and CBF fMRI at 4 and 7 T. Magn Reson Med 48(4): 589-593.

40. Febo M, Ferris CF (2014) Oxytocin and vasopressin modulation of the neural correlates of motivation and emotion: results from functional MRI studies in awake rats. Brain Res 1580: 8-21.

41. Madularu D, Yee JR, Kenkel WM, Moore KA, Kulkarni P, et al. (2015) Integration of neural networks activated by amphetamine in females with different estrogen levels: a functional imaging study in awake rats. Psychoneuroendocrinology 56: 200-212.

42. Goense JB, Logothetis NK (2006) Laminar specificity in monkey V1 using high-resolution SE-fMRI. Magn Reson Imaging 24(4): 381-392.

43. Liang Z, King J, Zhang N (2011) Uncovering intrinsic connectional architecture of functional networks in awake rat brain. J Neurosci 31(10): 3776-3783.

44. Miller DK, Bowirrat A, Manka M, Miller M, Stokes S, et al (2010) Acute intravenous synaptamine complex variant KB220 "normalizes" neurological dysregulation in patients during protracted abstinence from alcohol and opiates as observed using quantitative electroencephalographic and genetic analysis for reward polymorphisms: part 1, pilot study with 2 case reports. Postgrad Med 122(6): 188-213.

45. Blum K, Chen TJ, Morse S, Giordano J, Chen AL, et al. (2010) Overcoming qEEG abnormalities and reward gene deficits during protracted abstinence in male psychostimulant and polydrug abusers utilizing putative dopamine $\mathrm{D}(2)$ agonist therapy: part 2. Postgrad Med 122(6): 214-226.

46. Blum K, Chen AL, Giordano J, Borsten J, Chen TJ, et al. (2012) The addictive brain: all roads lead to dopamine. J Psychoactive Drugs 44(2): 134-143.

47. Chen TJ, Blum K, Payte JT, Schoolfield J, Hopper D, et al. (2004) Narcotic antagonists in drug dependence: pilot study showing enhancement of compliance with SYN-10, amino-acid precursors and enkephalinase inhibition therapy. Med Hypotheses 63(3): 538-548.
48. Brown RJ, Blum K, Trachtenberg MC (1990) Neurodynamics of relapse prevention: a neuronutrient approach to outpatient DUI offenders. J Psychoactive Drugs 22(2): 173-187.

49. Chen TJ, Blum K, Waite RL, Meshkin B, Schoolfield J, et al. (2007) Gene $\backslash$ Narcotic Attenuation Program attenuates substance use disorder, a clinical subtype of reward deficiency syndrome. Adv Ther 24(2): 402414.

50. K Blum, D Allison, MC Trachtenberg, RW Williams (1988) Reduction of both drug hunger and withdrawal against advice rate of cocaine abusers in a 30 day inpatient treatment program by the neuronutrient Tropamine. Curr Ther Res 43(6): 1204-1214.

51. Blum K, Chen AL, Chen TJ, Braverman ER, Reinking J, et al. (2008) Activation instead of blocking mesolimbic dopaminergic reward circuitry is a preferred modality in the long term treatment of reward deficiency syndrome (RDS): a commentary. Theor Biol Med Model 5: 24.

52. Dahlgren A, Wargelius HL, Berglund KJ, Fahlke C, Blennow K, et al (2011) Do alcohol-dependent individuals with DRD2 A1 allele have an increased risk of relapse? A pilot study. Alcohol Alcohol 46(5): 509513.

53. Szutorisz H, DiNieri JA, Sweet E, Egervari G, Michaelides M, et al (2014) Parental THC exposure leads to compulsive heroin-seeking and altered striatal synaptic plasticity in the subsequent generation. Neuropsychopharmacology 39(6): 1315-1323.

54. K Blum, RD Badgaiyan, Z Demotrovics, J Fratantonio, G Agan, et al. (2015) Can Genetic Testing Provide Information to Develop Customized Nutrigenomic Solutions for Reward Deficiency Syndrome? Clin Med Rev Case Rep 2(1).

55. Blum K, Meshkin B, Downs BW (2006) DNA based customized nutraceutical "gene therapy" utilizing a genoscore: a hypothesized paradigm shift of a novel approach to the diagnosis, stratification, prognosis and treatment of inflammatory processes in the human. Med Hypotheses 66(5): 1008-1018.

56. Thanos PK, Hamilton J, O’Rourke JR, Napoli A, Febo M, et al. (2016) Dopamine D2 gene expression interacts with environmental enrichment to impact lifespan and behavior. Oncotarget 7(15): 1911119123.

57. K Blum, J Femino, ST Teitelbaum, J Giordano, M Oscar-Berman, GMS (2013) Molecular Neurobiology of Addiction Recovery. The 12 Steps Program and Fellowship. Springer, New York, USA.
This work is licensed under Creative

Commons Attribution 4.0 Licens

DOI: 10.19080/GJARM.2017.01.555556
Your next submission with Juniper Publishers will reach you the below assets

- Quality Editorial service

- Swift Peer Review

- Reprints availability

- E-prints Service

- Manuscript Podcast for convenient understanding

- Global attainment for your research

- Manuscript accessibility in different formats

( Pdf, E-pub, Full Text, Audio)

- Unceasing customer service

Track the below URL for one-step submission https://juniperpublishers.com/online-submission.php 